\title{
Geography in a Parallel World
}

\section{Samigullina G.S.}

Kazan Federal University, Institute of Management, Economics and Finance, Kazan, 420008, Russia

\section{Doi:10.5901/mjss.2015.v6n3p770}

\begin{abstract}
The purpose of this article is to give a retrospective analysis of the school of geographical education in the world and Russia to return the geography of educational standards, its scientific and applied aspects.
\end{abstract}

Keywords: geography, geographic education, the state education standard.

Today in many countries there is a so-called "geographical Renaissance". International Geographical Union, in existence since 1871, and included in its membership the Commission on geographical education, existing since 1952, one of the priority tasks of its activity was determined by carrying out at the international level, the idea of the importance of geographic education in primary and secondary school, demonstrating its advantages in continuing education.

The international Charter on geographical education, adopted by the International Geographical Union (IGU) in 1992 and drew attention to: the right to education includes the right to a high level of geographical education, which is a reasonable combination of commitment to their country and global cooperation. EASC recommend this Charter to all peoples and governments of the world and recognizes the forms and principles represented in it, as a basis for ensuring a sufficient level of geographical education in all countries of the world.

The recommendations of the UNESCO education in the XXI century geography was named among the four key human knowledge, along with philosophy, computer science and foreign languages.

Since p. P. Semenov-Tian-Shansky geography has taken a worthy place in the Russian educational space [Geography,2004].

In modern Russia the relevance of geography in education, on the one hand marked by the Concept of update of geographical education in Russian schools" proposed by the Council on the problems of geography RAO.

On the other hand, the situation changed with the adoption of the concept of vocational education(2004). Attempts methodical journal "Geography" under the direction of O. N. Korotova with the participation of the General staff of the Armed forces, Parliamentary parties to rectify the situation, when the subject in the year of its 300-year existence was on the verge of washing out of the curriculum, or to have failed, partly because of summer vacations teachers and teaching staff of pedagogical universities.

Russian education is the situation of the USA in the beginning of XX century, when the number of hours of study of geography is strongly reduced. The US is facing an acute problem of loss of national competitiveness. About the seriousness of the problem and the urgency of reforming the educational system in the United States can be judged from the title of one of the reports, which was announced at the state level in 1983: "the Nation is in danger". Public opinion polls showed that U.S. citizens don't know their neighbors, time zones, etc.

In 2000's he completed a long-term educational program of the USA, which were allocated to region 4 educational history and native language, mathematics, natural discipline (biology, chemistry, physics), geography.

In a country where the intensified work of the Russian geographical society, optimization in the sphere of higher professional education, led firstly, mixing physical and economic-geographical branches of science, with characteristic objects and subjects of study; secondly, the loss of structural integrity of the academic and pedagogical geographical education.

So part of the departments of geography faculty KSU was in the Institute of ecology (after August 28, 2014), the pedagogical faculty in the two departments were in the Institute of management, Economics and Finance in the vicinity of the departments are very far from pedagogy. Homeland optimization education - South Korea, faced after World War II with the problem of imbalance between the educational needs of the population and supply of educational services by the state.

The solution was brilliant - South Korea has left, it is the investment in education and ensure that $70 \%$ of the population under the age of 40 years has not just higher education, but it is a competitive specialists, which partly caused 
the signing of the Bologna agreement.

From basic curricula geography has moved on Russian television, wait for various charity shows with recognizable representatives of politics, show business. What subject has crossword-sharedmem potential. Usually this program with the intention to help children's homes, shelters, etc. Seemed good and godly thing.

But there is one thing - the school of television and different goals. School educational goals do not leave time and effort on entertainment, implemented content-criterial approach to the results of development of educational programs. Where will swim boatswain, floating on the system of "river-sea" that failed during the television program "Who wants to be a millionaire?" to answer (and room to help) to the question "what source of the river lies North of the mouth" (as alternatives given the river Volga and Lena).

Famous showmen Nightingale Russian pop stars and famous parodist in the same television program, a charity game lost recruited win, not answering the question "Which of the two Islands - Greenland or Madagascar more?" hall to help, also failed.

The formation of ideas about geography and its role in the development of the planet man of geographical knowledge as a component of the scientific picture of the world presupposes a standard of basic education on December 17,2010

But is it possible achieve such a lofty goal at the time the load when in the presence of one class set of the teacher of geography is not obtained and a half.

The subject provided instructional support imaginable profiles and subprofiles (history and political science, biological, linguistic, economic, legal, mathematical, technological, military-sports and so on) remains non-effected in graduating class (Maksakovsky B. N.,1997).

Having, for example, the textbook "problem Solving for maps", we don't have any hours in the physical and mathematical profile [PL.1].

Table \#1. Teaching materials for geography

\begin{tabular}{|l|l|}
\hline \multicolumn{1}{|c|}{ Profiles } & Teaching Materials \\
\hline Humanitarian & Choline Century. N. The geography of human activity. M: Education,1998. \\
& Maksakovsky VP Geographical picture of the world in 3 parts. \\
& Kamilova, S. Urbanology. M: Education,1997. \\
& Vinokurov N. F., Trushin Century Century global ecology. M: Education,1997. \\
& Vinokurov N. F. and other natural resources. M: Education,1998. \\
& A. Darinskii Century Modern world. \\
& Demina T. A. Ecology of natural resource management. \\
& Smooth Y. N., Lavrov, S. B. global geography. M: Bustard,1998. \\
& Baburin C. L. Geography of the Russian Diaspora. M: Education,2001. \\
& Rodionova I. A., Choline Century. N. Political map of the world. Handbook for applicants to \\
& universities. M: Unique Center,1998. \\
& Kolesov C. A., Mironenko, N... Geopolitics and political geography. M.: Aspect Press,2001 \\
\hline Science & Kucher T. C., Kalashikov Imperial family Medical geography. M: Education,1998. \\
& Levitsky, I. Y., Engleska J. C. Solution of problems from the maps. M: Education,2001. \\
& Komisarova ie, the Cartography with the basics of topography. M: Education,2001. \\
& Koronovskii N. In. Geology.10-11. M: Bustard,2005. \\
\hline Socio-economic & Choline Century. N. The geography of human activity. M: Education,1998. \\
& The plisetski E. L.. Commercial geography. M: Education,1998. \\
& Lobzhanidze A. A.. the Geography of Russia: ecological and economic aspects. M: \\
& Education,2001. \\
& Solov'ev, I. B. and other fundamentals of business. M: Education,2001. \\
& Malbec. Ya, the basics of geography. M: Education,2001. \\
\hline
\end{tabular}

In profile the school is not limited opportunity for learning and native land $[2,3]$.

The theory of compromise, of which the author was Professor KSU R., Husiev, convincingly demonstrates the constructive possibilities of the subject when solving, for example, problems of raising to the design level Nizhnekamsk reservoir, development of special economic zone "Alabuga" and so on

The theory of compromise was the basis of the initiatives of the first President of Tatarstan M. W. Shaimiev regulatory challenges in the use of Nizhnekamsk reservoir with the participation of the Republic of Bashkortostan. Perm, Ulyanovsk regions. 
In the context of globalization of environmental crisis is becoming increasingly important concept of global sustainable development based on fundamental knowledge of the geographical and natural Sciences as evidenced by existing in the Republic scientific school And. So gaysina [4].

It is well known that the consideration of environmental problems humanity to biological sense - yesterday's day of the seven global environmental problems, only two are of biological nature-reduction species composition of animals and plants; the rest of geoecological plan (Rio de Janeiro,1991).

The place and time of inclusion of environmental issues in the structure and content of Russian education is not still solved. There is an opinion of the necessity of introducing an integrated course in geography, biology, chemistry, with the aim, on the one hand, elimination of discrete ecological picture of the world, formed in the school and devoid of integrity, on the other hand, avoid duplication of material in other disciplines (VP Heads,2004).

Geography, first, as the only discipline that studies the Trinity "man-nature-society" could take its rightful place in environmental education. Secondly, the ecological paradigm is most consistent with the nature of humanitarization of education. Another argument in favor of our subject - the Earth Charter, the Lucerne Declaration, many new textbooks, written by geographers, S. Camarillas, N. F. Vinokurova and so on [1,5].

Tautological the situation of the presence of absence of a subject in the curricula of Russian schools is multiplied by the dilemma.

So, staying in the classroom the learning system, where the peculiarity of the method is paternalism, a ban on interpersonal communication and 5\% participation of students in the goal setting lesson, we accept the standards aimed at creating a social situation of development of students trying to enter learning technologies, which have no relation, no whole-class education system, nor to the principles of Russian education.

We provide students with educational services in terms of choice of individual trajectories of education, deliberately cutting off the path to the philosophical study of the subject.

Discussion (discussion). Russia is a participant of the International project "open education", the essence of which was the formation of a unified scientific picture of the world, part of which is the geographical picture of the world, obtained in the course of research and practical work in the field of modern geography, reflecting the people's understanding of nature and society, his attitude towards them $[6,7,8]$.

It remains to hope that the wind of change in education will be us in a circle, and spiral development.

\section{References}

The Lucerne Declaration on geographical education for sustainable development // Geography and ecology in the school of the 21st century. - 2008. No. 1. - S. 35-41.

Samigullina, S. On the teaching of geography in terms preprofile training. Modern problems of geography, population and labour market: proceedings of the conference. - Kazan: publishing house "tan-dawn", 2003. - S. 156-162.

Samigullina, S. the Use of business games in the course of economic and social geography of Russia. Geography and ecology in the school of the XXI century. - 2008. No. 5. - S. 73-75.

Samigullina G. S. Formation of creative pedagogical system of continuous environmental education Life Science Journal 2014; 11(8s) S. 443-459.

Haubrich $\mathrm{H}$. and others Lucerne Declaration on geographical education for sustainable development // Geography and ecology in the school of the 21st century. - 2008. No. 1. - S. 35-41.

Scientific-pedagogical activity Y. C. Babanov (1931-1995,), Professor of physical geography at the Kazan state pedagogical University (tggu) (to the 80th anniversary of birthday) Gaisin I. T., Gaisin R. I. //Environmental consulting. - 2011. No. 3. - S. 22-24.

Integration of the systems of higher vocational education and training teachers of geography of the Republic of Tatarstan / Samigullina, S., Gaisin R. I. //Modern research of social problems (scientific electronic journal). - 2012. - № 4. - S. 59.

Gaisin, I.T., Biktimirov, N.M. Migration processes in the Republic of Tatarstan in the second half of the 20th and in the th early of 21st centuries: Ethnic and social aspects. Middle - East Journal of Scientific Research, 20 (12), pp. 1761-1766

Samigullina, G.S.,Moiseeva, L.V., Gaisin, I.T.,Vlasova, E.I. Meta-methodological implementation of creativity in ecogeographical education disciplines. Life Science Journal, 11 (9 SPEC. ISSUE), 73, pp. 341-345.

Biktimirov, N.M., Gaisin, R.I., Gaisin, I.T. The use of new methodologies for demographic investigations in national-territorial subdivisions of Russia. Life Science Journal, 11 (SPEC. ISSUE 8), pp. 194-197.

Urazmetov, I.A., Smirnova, E.V. (2014). Ecological state of water and soil of natural-anthropogenic landscapes in the oil-producing regions. Mediterranean Journal of Social Sciences, 5 (18 SPEC. ISSUE), pp. 367-372.

Urazmetov, I.A., Smirnova, E.V., Kadyrova, R.G. Features of the soil of subboreal semihumid landscape zone within urbanized areas. Mediterranean Journal of Social Sciences, 5 (18 SPEC. ISSUE), pp. 373-377. 